学術・技術論文

\title{
重力平衡する対象物の転がりによる操り
}

原田研 介* 川嶋大雅* 金子 真*

\section{Rolling Based Manipulation under Gravitational Equilibrium}

Kensuke Harada*, Taiga Kawashima* and Makoto Kaneko*

\begin{abstract}
This paper discusses the manipulation of an object under equilibrium where the object makes rolling contact with the plate attached at the tip of the arm. We assume that the object satisfies the neighborhood equilibrium [1], where an object with rolling contact can automatically find another equilibrium state close to the original one even when the current one is broken due to the change of input. For always guaranteeing the neighborhood equilibrium, we newly define the contact stable region on the object surface. By utilizing the contact stable region, we propose a control scheme for manipulating an object from one to the desired position on a plate whose posture is controllable. Numerical example is also shown to explain our idea.
\end{abstract}

Key Words: Equilibrium Grasp, Neighborhood Equilibrium, Rolling Contact, Nonholonomic Motion Planning, Manipulation

\section{1. 緒言}

ロボットハンド（以下ハンドと略記）は様々な複雑な作業を 実現する潜在的可能性を秘めている。ハンドが実現する典型的 な作業として，対象物の操りがある．従来多くの研究において， ハンドで対象物を操るとき, 対象物は Force Closure と呼ばれ る形態でハンドから拘束されてきた. Force Closureでは, 対 象物は十分な本数の指で把握されており, 指力により任意の合 力・合モーメントを生じさせることが可能である。それに対し て，対象物を平衡把握することを考える．把握された対象物は, それにはたらくすべての接触力が釣り合うときに平衡する。平 衡把握とは, Force Closure を含む概念であり, 対象物の平衡 を可能にする把握形態として定義される [2]. このため, 平衡把 握は通常, Force Closureよりも対象物に加わる拘束は弱くな る. ハンドやアームが対象物を平衡把握の下で操ることが可能 ならば, Force Closure を仮定するよりも少ない数の指で対象 物の操りが実現されることが期待できる。ただし, 従来平衡把 握下の対象物の操りに関しては, ほとんど研究が行われていな い. そこで, 本研究は重力平衡する対象物の一般的な操り理論 の構築を行うことを目的とする。

Fig. 1 (a) は本研究で用いる把握形態を概念的に表したもの であり, 単一の対象物が単一アームの先端リンクの上に置かれて 重力平衡を満足している。この把握形態は, 等価的に Fig. 1 (b) のように，傾斜角度の制御が可能な平板とその上に置かれた対

原稿受付 2000 年 12 月 8 日

*広島大学工学部

${ }^{*}$ Hiroshima University
象物として考えることができる．ここで，平板の上に棈円体の 対象物を置いた場合を考え (Fig. 1 (c)), 平板の角度を序々に増 加させる. Fig. 1 (d) に示すように, 平板の傾き $\alpha$ がある程度の 角度まで, 対象物は自動的に新しい平衡状態に移行することが 可能である。この新たな平衡状態を見つける現象を文献 [1]にお いて,「近傍平衡」と定義した。この近傍平衡を利用すれば, 重 力平衡する対象物の操りが容易になることが期待できる。そこ で，この近傍平衡を満足する対象物の位置と姿勢を制御するこ とを考える. Fig. 1 (c) に示すような二次元モデルでは, 平板の 傾き角度と対象物の姿勢が一対一に対応するため, 対象物の位

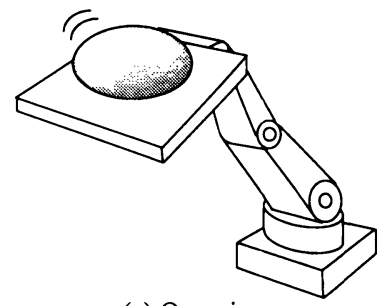

(a) Overview

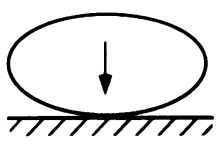

(c) 2D model

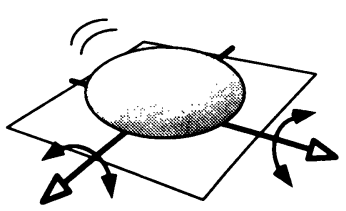

(b) Equivalent model

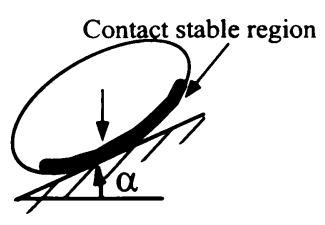

(d) 2D model with inclination
Fig. 1 Manipulation under neighborhood equilibrium 
置・姿勢の制御のための軌道計画は比較的容易である。それに 対して Fig. 1 (b) に示すような三次元モデルの場合, 対象物と 平板とが転がり接触を保つため, 接触点の速度に関して三次元 の拘束が存在することになる。この拘束は非ホロノミックな拘 束であることが知られている。非ホロノミックな拘束の下では, 平板の傾き角と対象物の位置·姿勢は，その位置・姿勢に至るま での経路に依存するため，一対一に対応しない。このため，対 象物の位置・姿勢の制御のための軌道計画は困難になる。この ような転がり接触下の非ホロノミック軌道計画問題は $\operatorname{Li} ら[5]$ によって最初に取り組まれた。彼らは，球体を平板上で転がす 場合を想定し, 平板上で接触点軌道として一辺の長さが球の大 円の $1 / 4$ の大きさの正方形を描くと球の姿勢角が $\pi / 2[\mathrm{rad}]$ た け変化する特徵に着目し, Lie Bracket Motion を提案した。ま た,この Lie Bracket Motionを利用し，接触点軌道の計画法 を論じた。

以上のことを考慮し，本論文では重力平衡する，一般的な 次元対象物の操り問題について議論する. まず初めに, 系の幾 何学モデルを紹介する. 次に，4 章では Montana [19]によって 提案された接触安定理論を平衡把握された系に拡張することで, 対象物表面上に接触安定を満足する領域（接触安定領域）が定 義できることを示す．対象物と平板との接触がこの領域内で起 こると, 常に平衡状態は安定平衡となるため, 対象物が平板か ら転げ落ちるような現象を避けることが可能となり，常に近傍 平衡が満足される。この接触安定領域の制限の下で, 対象物と 平板との接触状態を初期状態から望みの状態に移行させるよう な，転がりによる操り問題を考える。平衡把握された系では，対 象物が完全には拘束されないため, 目標軌道を実現するアーム の関節軌道は一意には求まらないが，5章では準静的な運動を 仮定することで関節軌道が一意に求まることを示す. 6 章では， 目標軌道として対象物とアームとの接触点軌道を計画する。 Li ら [5]の軌道計画法は, 球にしか適用できないが, 本手法は対象 物上での接触点軌道として測地線を用いた正三角形を描くため, 球以外の対象物にも適用可能である点が, 彼らの手法とは異な る.このような問題に対する解は無限に存在するが, 本論文で 提案する方法は, 特に回転棈円体対象物に対しては常に解への 到達性が保証されることを示す。最後に, 提案する手法の有効 性を示すため, シミュレーション結果, ならびに 2 自由度ア一 ムと半球対象物を用いた実験結果を示す。

\section{2. 関連研 究}

転がり接触の幾何学に関する研究として, Kerr ら [3], Mon$\operatorname{tana}[4]$ は転がり接触における接触状態の幾何学的関係式を導 出した。また, Li ら [5]は, 転がり接触を非ホロノミックな拘 束をもつ問題として, 可制御性の判定, 球体に対する軌道計画 を行った。転がり接触の幾何学や操り全般については, Murray ら [12]の著書において詳説されている.

転がり接触を利用した対象物の操りの研究としては, Force Closure を仮定したものが多く行われている. Coleら [6], Paljug ら [7], Sarkar ら [8] は転がり接触を仮定して対象物の重心の位 置・姿勢の制御を行った。 また, Bicchi ら [9], 三平ら [10], Han ら [11] は転がり接触を仮定して対象物の接触座標の制御の問題
を扱っている。

近年, Force Closure が成立しないような弱い拘束下での操 りの研究が行われている. Trinkleら [13] は摩擦なし接触の下 で平衡把握の構成や，その安定性に関して議論した. Kaneko ら [14] はテーブルに置かれたピラミッド型対象物を平衡把握す るための戦略を論じた。 また，対象物に対して，弱い拘束を仮定 する操り形態として, Dynamic Manipulationがある. Lynch ら [15], 荒井ら [16] は単一のアームにより, 対象物の Dynamic Manipulationを実現させる研究を行っている.

以上のように筆者らの知る限り，転がり接触を利用して Force Closure が成立しないような条件下で対象物を正確に操る研究 は前例がない。

\section{3. モ デル 化}

\section{1 対象物の運動拘束}

Fig. 2 に，本研究で用いるシステムのモデルを示す. 図に示 すとおり，アームの先端リンクの平板上に対象物が置かれてお り，対象物は平板と転がり接触をする。 $\Sigma_{R}$ は基準座標系を表 し， $\Sigma_{O}$ は対象物の重心に固定された座標系， $\Sigma_{A}$ はアームの 先端リンクに固定された座標系を表し， $\Sigma_{C O}, \Sigma_{C A}$ はそれぞれ 対象物側，アーム側の接触点に固定された座標系を表す。また， $\Sigma_{L O}, \Sigma_{L A}$ はそれぞれ対象物，アームの先端リンクに固定され た座標系で，対象物とアームが接触する瞬間にそれぞれ $\Sigma_{C O}$, $\Sigma_{C A}$ と一致する. $\boldsymbol{p}_{O}, \boldsymbol{R}_{O}$ は基準座標系から見た $\Sigma_{O}$ の位置べ クトル，ならびに姿勢を表す回転行列であり，同様に $\boldsymbol{p}_{A}, \boldsymbol{R}_{A}$ は基準座標系から見た $\Sigma_{A}$ の位置べクトル，ならびに姿勢を表 す回転行列である。 ${ }^{O} \boldsymbol{p}_{C O}$ は $\Sigma_{O}$ から見た $\Sigma_{C O}$ 原点の位置べ クトルであり, ${ }^{A} \boldsymbol{p}_{C A}$ は $\Sigma_{A}$ から見た $\Sigma_{C A}$ 原点の位置べクト ルである。

接触点において Pure Rolling を仮定する.このとき， $\Sigma_{L O}$ と $\Sigma_{L A}$ の原点の並進速度，また接触点の法線 $(\mathrm{z}$ 軸) まわり の回転速度は一致することになる。このため, 対象物の運動は 拘束を受けることになる。拘束の関係式は次式のとおりに表さ 机る。

$$
\boldsymbol{D}_{O} \boldsymbol{T}_{O} \dot{\boldsymbol{x}}_{O}=\boldsymbol{D}_{A} \boldsymbol{J} \dot{\boldsymbol{\theta}}
$$

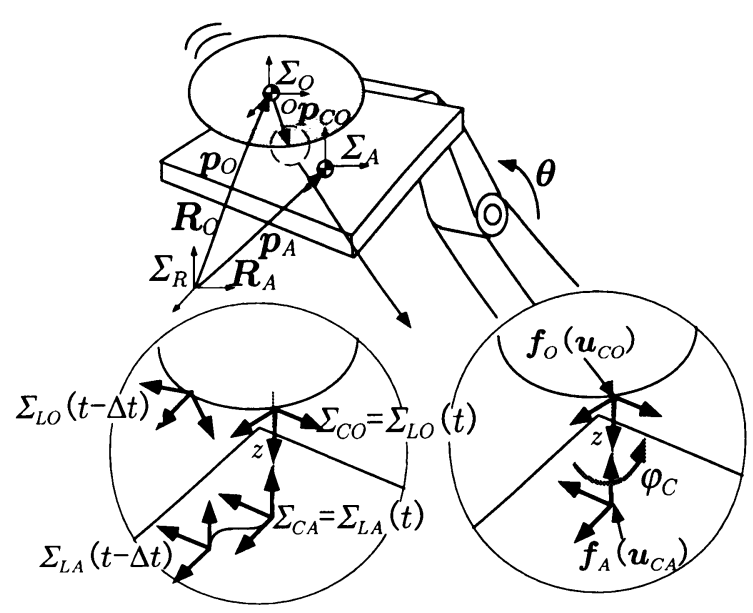

Fig. 2 Model of the system 
ここで,

$$
\begin{aligned}
& \boldsymbol{D}_{O}=\left[\begin{array}{cc}
\boldsymbol{I}_{3} & -\left(\left(\boldsymbol{R}_{O}^{O} \boldsymbol{p}_{C O}\right) \times\right) \\
\mathbf{0} & \boldsymbol{e}_{3}^{T} \boldsymbol{R}_{L O}^{T}
\end{array}\right] \in R^{4 \times 6} \\
& \boldsymbol{D}_{A}=\left[\begin{array}{cc}
\boldsymbol{I}_{3} & -\left(\left(\boldsymbol{R}_{A}^{A} \boldsymbol{p}_{C A}\right) \times\right) \\
\mathbf{0} & \boldsymbol{e}_{3}^{T} \boldsymbol{R}_{L A}^{T}
\end{array}\right] \in R^{4 \times 6} \\
& \dot{\boldsymbol{x}}_{O}=\left[\begin{array}{ll}
\dot{\boldsymbol{p}}_{O}^{T} & \dot{\boldsymbol{\alpha}}_{O}^{T}
\end{array}\right]^{T} \in R^{6} \\
& {\left[\begin{array}{c}
\dot{\boldsymbol{p}}_{O} \\
\boldsymbol{\omega}_{O}
\end{array}\right]=\boldsymbol{T}_{O} \dot{\boldsymbol{x}}_{O}} \\
& {\left[\begin{array}{c}
\dot{\boldsymbol{p}}_{A} \\
\boldsymbol{\omega}_{A}
\end{array}\right]=\boldsymbol{J} \dot{\boldsymbol{\theta}}}
\end{aligned}
$$

であり, $\boldsymbol{I}_{3}$ は $3 \times 3$ 単位行列, $\boldsymbol{e}_{3}=\left[\begin{array}{lll}0 & 0 & 1\end{array}\right]^{T}, \boldsymbol{\theta}$ は関節变位 ベクトル， $\alpha_{O} \in R^{3}$ は対象物の姿勢を表すオイラー角によって 構成されるべクトル， $\boldsymbol{T}_{O}$ は回転角速度とオイラー角の速度の 間の変換を行う行列である. また, $(* \times)$ は外積と等価な歪対称

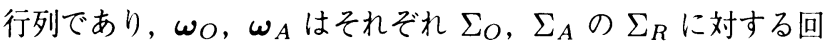
転角速度ベクトルである。

\section{2 接触座標}

接触点の位置を表すべクトル ${ }^{O} \boldsymbol{p}_{C O},{ }^{A} \boldsymbol{p}_{C A}$ はそれぞれ対象 物，アーム先端リンク上に存在するため, 二次元ベクトル $\boldsymbol{u}_{C O}$, $\boldsymbol{u}_{C A}$ を用いて ${ }^{A} \boldsymbol{p}_{C A}=\boldsymbol{f}_{A}\left(\boldsymbol{u}_{C A}\right),{ }^{O} \boldsymbol{p}_{C O}=\boldsymbol{f}_{O}\left(\boldsymbol{u}_{C O}\right)$ のよ うに表される。また，接触状態は五つの変数を用いて表すこと ができる (Fig. 2)。これらは, $\boldsymbol{u}_{C O} \in R^{2}, \boldsymbol{u}_{C A} \in R^{2}$, なら びに $\Sigma_{C A}$ と $\Sigma_{C O}$ の $x$ 軸のなす角 $\varphi_{C} \in R^{1}$ である [4]. こ こで, $\varphi_{C}$ については, $\Sigma_{C O}$ の $x$ 軸を $\Sigma_{C O}$ の $z$ 軸まわりに $-\varphi_{C}[\mathrm{rad}]$ 回転させると $\Sigma_{C A}$ の $x$ 軸と一致する. 平板, 対象物 の表面の Curvature Form, Connection Form, Metric Tensor をそれぞれ $\mathcal{K}_{A}, \boldsymbol{T}_{A}, \mathcal{M}_{A}, \mathcal{K}_{O}, \mathcal{T}_{O}, \mathcal{M}_{O}$ とおく [4] [17]. 接触状態として Pure Rolling を仮定し, Montana [4] の定式化 を利用することで $\dot{\boldsymbol{u}}_{C O}$ は以下のように記述される。

$$
\dot{\boldsymbol{u}}_{C O}=\boldsymbol{C}\left(\boldsymbol{T}_{O} \dot{\boldsymbol{x}}_{O}-\boldsymbol{J} \dot{\boldsymbol{\theta}}\right)
$$

ここで,

$$
\begin{aligned}
\boldsymbol{C} & =\left[\mathbf{0} \boldsymbol{C}_{2}\right] \in R^{2 \times 6} \\
\boldsymbol{C}_{2} & =\mathcal{M}_{O}^{-1}\left(\mathcal{K}_{O}+\tilde{\mathcal{K}}_{A}\right)^{-1} \boldsymbol{E} \boldsymbol{R}_{L O}^{T} \in R^{2 \times 3} \\
\boldsymbol{E} & =\left[\begin{array}{ccc}
0 & -1 & 0 \\
1 & 0 & 0
\end{array}\right] \\
\boldsymbol{\mathcal { R }}_{\varphi} & =\left[\begin{array}{cc}
\cos \varphi_{C} & -\sin \varphi_{C} \\
-\sin \varphi_{C} & -\cos \varphi_{C}
\end{array}\right] \\
\tilde{\mathcal{K}}_{A} & =\boldsymbol{\mathcal { R }}_{\varphi} \mathcal{K}_{A} \boldsymbol{\mathcal { R }}_{\varphi}
\end{aligned}
$$

である. 式 (2) の導出は付録に示す. $\dot{\boldsymbol{u}}_{C O}$ が与えられると $\dot{\boldsymbol{u}}_{C A}$, $\dot{\varphi}_{C}$ は $\dot{\boldsymbol{u}}_{C O}$ の関数として一意に導出できる.つまり, 次式が 成立する [5].

$$
\left[\begin{array}{c}
\dot{\boldsymbol{u}}_{C A} \\
\dot{\varphi}_{C}
\end{array}\right]=\left[\begin{array}{c}
\mathcal{M}_{A}^{-1} \boldsymbol{R}_{\varphi} \\
\mathcal{T}_{O}+\mathcal{T}_{A} \boldsymbol{R}_{\varphi}
\end{array}\right] \mathcal{M}_{O} \dot{\boldsymbol{u}}_{C O}
$$

ここで，本論文での操り問題を以下のように明確に定義する。
[定義 1]：対象物の操り問題 近傍平衡を満足しながら, 接触座標である $\boldsymbol{u}_{C O}, \boldsymbol{u}_{C A}$, $\varphi_{C}$ を, 関節变数 $\boldsymbol{\theta}$ の操作で最終的にすべて目標值に収 束させる。

\section{4. 接触安定領域}

近傍平衡の一例として Fig. 1(d) で，棈円体対象物は平板の 傾き角がある程度まで安定平衡を満足するが，傾き角が大きく なると安定平衡とならないため近傍平衡を維持できないことを 述べた。このため，接触座標を望みの值に収束させるための軌 道計画は，不安定な状態を避けながら行う必要がある。ここで は，接触安定 (Contact Stability) [19]の概念を拡張すること で, 対象物上で近傍平衡を満足する領域を定義する．単一のア一 么と単一の対象物の接触に関して, 接触点の移動に伴う対象物 の姿勢の変化は以下のような式で記述できる.

$$
\Delta \dot{\psi}=A \Delta \psi
$$

ここで

$$
\begin{aligned}
& \boldsymbol{A}=\left[\begin{array}{cc}
\mathbf{0} & \boldsymbol{I}_{2} \\
\boldsymbol{A}_{21} & \boldsymbol{A}_{22}
\end{array}\right] \\
& \boldsymbol{A}_{21}=\boldsymbol{M}_{22}\left(f_{z} \boldsymbol{L}^{T}\left(\boldsymbol{\mathcal { K }}_{O}+\tilde{\mathcal{K}}_{A}\right)^{-1} \boldsymbol{L}\right. \\
& \left.-r_{z} f_{z} \boldsymbol{I}+\left[\begin{array}{ll}
r_{y} & -r_{x}
\end{array}\right]^{T}\left[\begin{array}{ll}
-f_{y} f_{x}
\end{array}\right]\right) \\
& \boldsymbol{A}_{22}=\boldsymbol{M}_{22} k_{f} f_{z} \\
& \Delta \boldsymbol{\psi}=\left[\begin{array}{lll}
\Delta \psi_{x} & \Delta \psi_{y} & \Delta \dot{\psi}_{x}
\end{array} \dot{\psi}_{y}\right] \\
& {\left[\begin{array}{lll}
\dot{\psi}_{x} & \dot{\psi}_{y} & \dot{\psi}_{z}
\end{array}\right]^{T}=\boldsymbol{R}_{L O}^{T}\left(\boldsymbol{\omega}_{O}-\boldsymbol{\omega}_{A}\right)} \\
& {\left[\begin{array}{lll}
r_{x} & r_{y} & r_{z}
\end{array}\right]^{T}={ }^{O} \boldsymbol{R}_{L O}^{T}{ }^{O} \boldsymbol{p}_{C O}}
\end{aligned}
$$

であり， $\left[\begin{array}{llll}f_{x} & f_{y} & f_{z}\end{array}\right]^{T}$ は $\Sigma_{L O}$ から見た接触力ベクトルである. なお， $\boldsymbol{M}_{22}$ や $\boldsymbol{L}$ の構成や，その他式（4）について詳しい議論 は文献 [19] を参照されたい. 式 (4) は文献 [19]の 2 本指の単 一対象物の把握に対する式を，単一の指に簡略化した式である. 式（4）に扔いて, 行列 $\boldsymbol{A}$ は $\boldsymbol{u}_{C O}, \boldsymbol{u}_{C A}, \varphi_{C}$ そして $\left[\begin{array}{lll}f_{x} & f_{y} & f_{z}\end{array}\right]^{T}$ の関数である. しかし, 行列 $\boldsymbol{A}$ が $\boldsymbol{u}_{C O}$ のみの 関数となれば, 対象物上の接触点を指定すると接触安定性が決 まることになり，対象物の表面上に接触安定領域を指定できる. まず，以下の仮定をおく。

[仮定 1]：準静的運動

対象物の運動は十分遅く, 各瞬間で平衡が成立する。

平衡状態にあるとき，対象物の重心は接触点の真上にある。つ まり，接触力ベクトルは以下のようにおくことができる。

$$
\left[\begin{array}{lll}
f_{x} & f_{y} & f_{z}
\end{array}\right]^{T}=-m g \frac{{ }^{O} \boldsymbol{R}_{L O}^{T}{ }^{O} \boldsymbol{p}_{C O}}{\left\|\boldsymbol{R}_{L O}^{T}{ }^{O} \boldsymbol{p}_{C O}\right\|}
$$

次に，対象物が接触する面は平板であるとする，平板では $\tilde{\mathcal{K}}_{A}=$ 0 が成立する.ここで, $\tilde{\mathcal{K}}_{A}$ は $\boldsymbol{u}_{C A}$ と $\varphi_{C}$ の関数であり, 行 列 $\boldsymbol{A}$ の他の成分は $\boldsymbol{u}_{C O}$ と $\left[f_{x} f_{y} f_{z}\right]^{T}$ の関数である. 以上の 仮定を定義することで, 行列 $\boldsymbol{A}$ は $\boldsymbol{u}_{C O}$ のみの関数となった。 つまり系の安定性は $\boldsymbol{u}_{C O}$ のみを指定することで決定され，接 


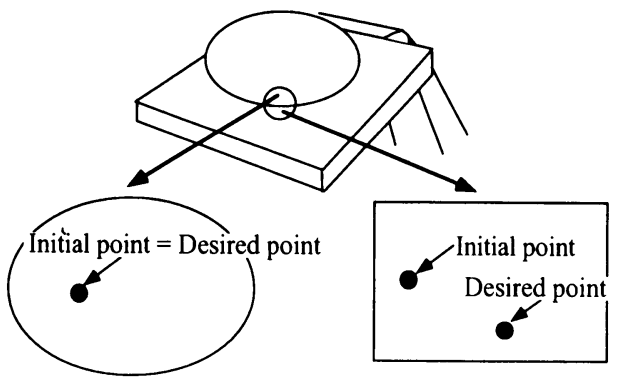

(a) Problem statement
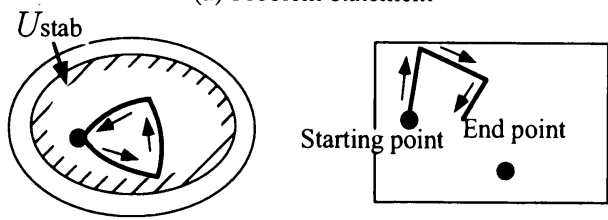

(b) Drawing a triangle on object satisfying the neighborhood equilibrium
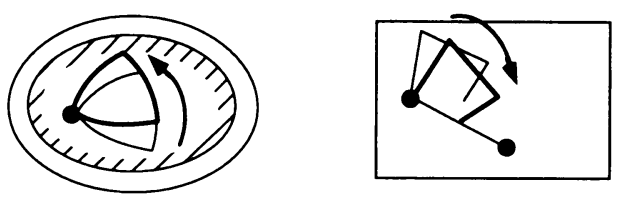

(c) Rotation of the triangle
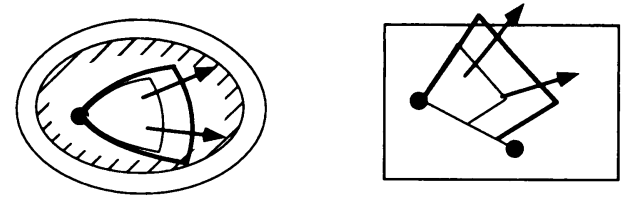

(d) Changing the size of triangle
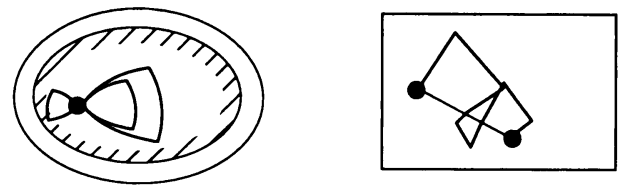

(e) Detection of desired trajectory

Fig. 3 Trajectory planning

触安定領域を以下のように $\boldsymbol{u}_{C O}$ の集合として定義できる.

$$
\mathcal{U}_{\text {stab }}=\left\{\boldsymbol{u}_{C O} \mid \max \left\{\operatorname{Re}\left(\lambda_{1}\right) \cdots \operatorname{Re}\left(\lambda_{4}\right)\right\}<0\right\}
$$

ここで, $\lambda_{1} \cdots \lambda_{4}$ は行列 $\boldsymbol{A}$ の固有值を表す. 6 章において軌 道計画を論じるが，その際接触安定領域を考慮し，この領域内 で接触点軌道の計画を行うことを考える。

\section{5. 関節軌道の導出}

本論文での操り問題は, 接触座標をアームの関節により操作 することと定義された。本章では, 接触点軌道が与えられた場 合の関節軌道の導出について議論する。まず, $\dot{\boldsymbol{x}}_{O}$ を $\dot{\boldsymbol{u}}_{C O}$ と $\dot{\boldsymbol{\theta}}$ の関数として表すことを考える.式 (1), 式 (2) を用いるこ とで, $\dot{\boldsymbol{x}}_{O}$ は $\dot{\boldsymbol{u}}_{C O}$ と $\dot{\boldsymbol{\theta}}$ の関数として次式のとおりに表すこと ができる。

$$
\begin{aligned}
\dot{\boldsymbol{x}}_{O} & =\boldsymbol{T}_{O}^{-1}\left[\begin{array}{c}
\boldsymbol{C} \\
\boldsymbol{D}_{O}
\end{array}\right]^{-1}\left(\left[\begin{array}{c}
\dot{\boldsymbol{u}}_{C O} \\
\mathbf{0}
\end{array}\right]+\left[\begin{array}{c}
\boldsymbol{C} \\
\boldsymbol{D}_{A}
\end{array}\right] \boldsymbol{J} \dot{\boldsymbol{\theta}}\right) \\
& \triangleq \boldsymbol{G}_{U} \dot{\boldsymbol{u}}_{C O}+\boldsymbol{G}_{\theta} \dot{\boldsymbol{\theta}}
\end{aligned}
$$

ここで, 行列 $\left[\boldsymbol{C}^{T} \boldsymbol{D}_{O}^{T}\right]^{T}$ はその構成より常に正則であること がいえ，逆行列をとることが可能である.

次に，仮定 1 で準静的運動を仮定した。このとき，付録に示 す式（B.6）が常に成立する。ここで, 付録より $\Theta\left(\boldsymbol{x}_{O}, \boldsymbol{\theta}, \boldsymbol{u}\right)$ は $\boldsymbol{H}_{G}$ より構成されていることが分かり, また $\boldsymbol{H}_{G}$ は $\boldsymbol{D}_{O} \boldsymbol{T}_{O}$, $\boldsymbol{E}_{O}$ より構成されている. $\boldsymbol{D}_{O} \boldsymbol{T}_{O}$ は $\boldsymbol{x}_{O}, \boldsymbol{u}_{C O}$ の関数であり, $\boldsymbol{E}_{O}$ はこれらの関数かあるいは定数の行列である.つまり, 式 （B.6）を微分することで, 次式を得る.

$$
\boldsymbol{\Theta}_{O} \dot{\boldsymbol{x}}_{O}+\boldsymbol{\Theta}_{U} \dot{\boldsymbol{u}}_{C O}=\mathbf{0}
$$

ここで, $\boldsymbol{\Theta}_{O}=\partial \Theta / \partial \boldsymbol{x}_{O}^{T}, \boldsymbol{\Theta}_{U}=\partial \Theta / \partial \boldsymbol{u}_{C O}^{T}$ である. 式 (7) と式（8）を連立させて $\dot{\boldsymbol{x}}_{O}$ を消去し, さらにその式を $\dot{\boldsymbol{\theta}}$ につ いて解くことにより, 次式が得られる。

$$
\Delta \boldsymbol{\theta}=-\left(\boldsymbol{\Theta}_{O} \boldsymbol{G}_{\theta}\right)^{-1}\left(\boldsymbol{\Theta}_{U}+\boldsymbol{\Theta}_{O} \boldsymbol{G}_{U}\right) \Delta \boldsymbol{u}_{C O}
$$

ここで, $\Delta *$ は*の変化量を表す.

以上のプロセスで, $\boldsymbol{u}_{C O}$ の軌道が与えられた場合の $\boldsymbol{\theta}$ の軌 道が計算された。近傍平衡にある対象物では，アームの関節が すべて固定されても対象物が運動自由度を持つため，式（1）, 式 (2) のみでは関節軌道を一意に導出することは不可能であ る.しかしながら，常に対象物が平衡状態にあると仮定すると， 関節変位の值に対して対象物の位置・姿勢が一意に定まるため, 式（B.6）を仮定して関節軌道を導出した。式（9）より，対象 物が十分ゆっくり動く限り，任意の $\boldsymbol{u}_{C O}$ に対する軌道が関節 を制御することにより実現できる。

\section{6. 軌道 計 画}

\section{1 軌道計画の概要}

前章での逆運動学問題では, 目標の接触点軌道が与えられた 場合の関節軌道の構成を論じた。次に, 目標の接触点軌道を構 成することを考える。接触座標である $\boldsymbol{u}_{C O}, \boldsymbol{u}_{C A}, \varphi_{C}$ のう ち, $\boldsymbol{u}_{C O}$ は操作されて, その目標点に到達していると仮定する （Fig. 3 (a)）。この仮定の下で，対象物上で閉軌道を描くような 接触点軌道を与えて，アーム上で望みの $\boldsymbol{u}_{C A}, \varphi_{C}$ を実現させ ることを考える。この軌道計画の概要は以下のとおりである.

$[\mathbf{1}]$ : 対象物上で接触点軌道として三角形を描く (Fig. $3(\mathrm{~b}))$. こ のとき，対象物は凸形状であるため，平板側の接触点軌道は始 点と終点が一致しないように，対象物側で三角形を描くことが 可能である。

$[2]$ : 対象物側の三角形を始点回りに回転させることで，アー 厶側の終点が，始点と目標点を結ぶ直線上に乗るようにする (Fig. 3 (c)).

$[\mathbf{3}]$ ：三角形の大きさを変えることで，平板側の終点の位置を目 標点に近づける（Fig. $3(\mathrm{~d}))$.

$[4]$ : 三角形を複数回描くことで， $\boldsymbol{u}_{C A}$ と $\varphi_{C}$ を同時に目標值 


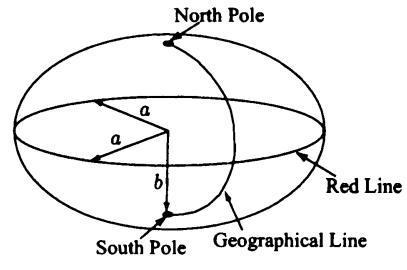

Fig. 4 Spheroid

\section{に収束させる（Fig. 3(e)）。}

\section{2 棈円体対象物に対する軌道計画}

対象物を棈円体に限定し，先に述べた軌道計画を行う。ここ では，対象物として楕円体のうち，2 本の軸長が等しい回転楕 円体を対象とする（Fig.4），一般性を失うことなく，棈円体上 で初期点と目標点は北極か南極にあるとする。このとき，初期 姿勢と最終姿勢で対象物と接する平板は水平になる。なお，対 象物上で極以外の点に初期点がある場合，まず対象物上の接触 点を極に移動させた後，軌道計画を行うものとする。また，目 標点が極以外の場合も同様に，目標点から逆時間で接触点を移 動させて極に到達させておくこととする。この仮定により以下 のことがいえる。

[補題 1] : $\boldsymbol{u}_{C O}$ の制限 $\boldsymbol{u}_{C O} \in \mathcal{U}_{s t a b}$ の制限の下, 対象物上で任意の点を初期点, 目標点とすることができる.

接触点軌道として, 対象物上で測地線により正三角形 この測地線による正三角形は以下のような特徽を持っている.

[1] 測地線は平面上での直線に対応する。よって，対象物上で接 触点軌道として測地線を描くと，平板上では直線が描かれる.

[2] 回転楕円体は対称な形をしている，よって，極を始点と して正三角形を描くと内角のうち二つは等しい角度を有する

(Fig. 5 (a)).

[3] ガウスーボンネの定理 [20]より，次式が成立する.

$$
q_{1}+2 q_{2}-\pi=\iint_{S} \kappa d S
$$

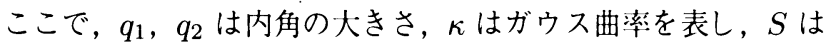
正三角形で区切られた領域を表す。ガウス曲率は常に正である ので, 三角形の内角の和は $\pi$ より大きくなる.つまり, 平板上 の接触点軌道で始点と終点は一致しない.

[4] 正三角形の辺長 $l$ が与えられたとする. 正三角形の内角は 辺長 $l$ の関数として一意に導出される.

[4]について，詳しくは付録に記述する，後に示す理由により， 二つの逆方向から描いた正三角形を組み合わせる (Fig. 5 (b)). この組み合わせを 1 ステップと考えると, 1 ステップでの $\boldsymbol{u}_{C A}$ と $\varphi_{C}$ の変化量である $\delta h, \delta \varphi_{C}$ は次式で与えられる.

$$
\begin{aligned}
\delta h\left(l_{L}, l_{R}\right)= & l_{L}-2 l_{L} \cos \left(q_{L 2}\left(l_{L}\right)\right) \\
& +l_{R}-2 l_{R} \cos \left(q_{R 2}\left(l_{R}\right)\right) \\
\delta \varphi_{C}\left(l_{L}, l_{R}\right)= & -\iint_{S_{R}} \kappa d S_{R}+\iint_{S_{L}} \kappa d S_{L}
\end{aligned}
$$

\footnotetext{
†対象物上で三つの辺の長さが等しい図形を拡大解积で正三角形と呼ぶ。
}

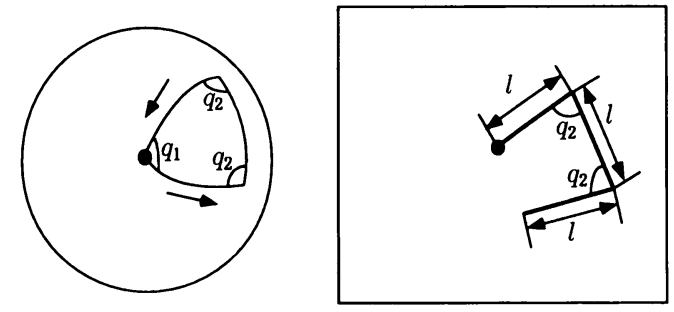

(a) Equilateral triangle on spheroid
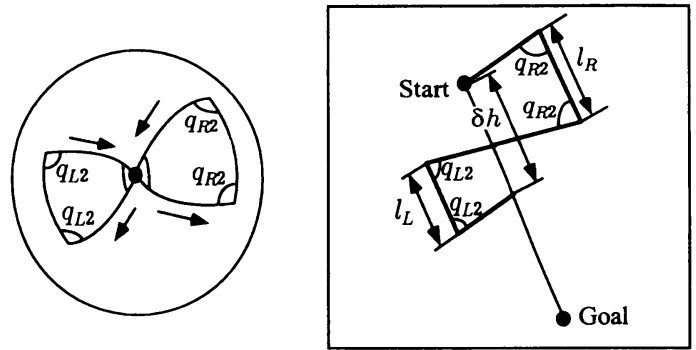

(b) Combination of two triangles

Fig. 5 Trajectory planning for spheroidal object

$$
\begin{aligned}
= & 2 q_{L 2}\left(l_{L}\right)+q_{L 1}\left(l_{L}\right) \\
& -2 q_{R 2}\left(l_{R}\right)-q_{R 1}\left(l_{R}\right)
\end{aligned}
$$

ここで，式（12）の第 1 行目は文献 [5]による.式（12）より， 逆方向から描いた二角形二つの大きさが同じなら， $\delta \varphi_{C}=0$ が 満足されることが分かる。 また，式 $(12) よ り ， \delta \varphi_{C}$ は三角形 の領域とガウス曲率の積を積分することにより得られる。三角 形の辺の長さが増加すれば面積は増加する関係にあり，ガウス 曲率は常に正であるため, $\delta \varphi_{C}$ は $l_{L}\left(l_{R}\right)$ に関して単調増加（隇 少）関数となる。つまり, 式 (12) より次式が成立する.

$$
\begin{aligned}
& \delta \varphi_{C}>-2 q_{R 1}\left(l_{\max }\right)-q_{R 1}\left(l_{\max }\right) \\
& \delta \varphi_{C}<2 q_{L 2}\left(l_{\max }\right)+q_{L 1}\left(l_{\max }\right)
\end{aligned}
$$

ここで, $l_{\max }$ は接触安定領域を出ない範囲で設定する, 三角形 の最大の辺長を表す。これより，

[補題 2]： $\varphi_{C}$ の制限 式 (13), 式 (14) の制限の下, 1 ステップで任意の $\varphi_{C}$ に 到達可能である。

このように，上式の制限内で任意の $\delta \varphi_{C}$ が実現できるため，二 つの三角形を組み合わせることとした。式 (11)，式 (12) を用 いることで, $\boldsymbol{u}_{C A}$ と $\varphi_{C}$ を同時に目標值に収束させる軌道計 画問題を次のように定式化できる.

Step 1 ：次式を満足する $l_{R}\left(\leq l_{\max }\right)$ を見つける.

$$
i_{1} \cdot \delta \varphi_{C}\left(l_{\max }, l_{R}\right)=\varphi_{C d}
$$

ここで, $i_{1}=\operatorname{int}\left(h_{d} / \delta h\left(l_{\max }, l_{\max }\right)\right)$ であり, $h_{d}, \varphi_{C d}$ は それぞれ $h, \varphi_{C}$ の目標値である.

Step 2 : 次式を満足する $l_{M}\left(\leq l_{\max }\right)$ を見つける.

$$
i_{2} \cdot \delta h\left(l_{M I} \cdot l_{M}\right)+i_{1} \cdot \delta h\left(l_{\max }, l_{R}\right)=h_{d}
$$


ここで, $i_{2}=\operatorname{int}\left(\left(h_{d}-i_{1} \cdot \delta h\left(l_{\max }, l_{R}\right)\right) / \delta h\left(l_{\max }, l_{\max }\right)\right)+1$ である。

Step 1 では, $0 \leq \varphi_{C d} \leq i_{1} \delta \varphi_{C}\left(l_{\max }, 0\right)$ の範囲で任意の $\varphi_{C d}$ が実現される, また, $\delta h\left(l_{L}, l_{R}\right)$ は $l_{L}, l_{R}$ に関して単調 増加関数であるため ${ }^{\dagger}, i_{1}$ の定義より $i_{1} \cdot \delta h\left(l_{\max }, l_{R}\right)<h_{d}$ が満足される。一方, Step 2 では, Step 1 で描いた軌道 に加えて，二つの同じ大きさの三角形を描くことで $\varphi_{C}$ を 変化させることなしに $h_{d}$ を実現している． $i_{2}$ の定義より, $\left(i_{2}-1\right) \delta h\left(l_{\max }, l_{\max }\right) \leq h_{d}-i_{1} \delta h\left(l_{\max }, l_{R}\right) \leq i_{2} \delta h\left(l_{\max }, l_{\max }\right)$ であるため, $l_{M}$ が存在する。 また，回転棈円体の形状の対称 性から，任意の $h_{d}$ が実現されると，任意の $\boldsymbol{u}_{C A d}$ が実現され る.つまり,

[補題 3]: $\boldsymbol{u}_{C A d}$ の実現

平板は十分に広いとする. Step 1 で $\varphi_{C d}$ が実現できる
と, Step 2 で任意の $\boldsymbol{u}_{C A d}$ が実現される.

以上, 補題 1 から 3 より, 本アルゴリズムの可到達性がいえる. 最後に, 本アルゴリズムは $\varphi_{C d} \geq 0$ の場合に対して適用可能 であるが, $\varphi_{C d} \leq 0$ の場合にも式 $(15)$, 式 (16)の $l_{\max }, l_{R}$ をそれぞれ $l_{L}, l_{\max }$ に置き換えることで適用できる. 以上, 補 題 $1,2,3$ より次の定理が導出される.

[定理 1]：目標接触状態の実現

本論文で提案する軌道計画では, $\boldsymbol{u}_{C O} \in \mathcal{U}_{s t a b}$, ならびに, 式 (13), 式 (14) の制限の下，任意の接触状態が実現でき る。

7. シミュレーション

まず， 6 章で提案した軌道計画を確認する．6.2 節では回転 棈円体に対して軌道計画を行ったが, 本章では対象物として半 径は $22[\mathrm{~mm}]$ の半球を用いる. 半球も対称な形状をしているた め, 6.2 節の軌道計画法を適用することが可能である。接触安 定性を計算することにより $l_{\max }=20[\mathrm{~mm}]$ と設定した。また， 接触座標の目標值は $\boldsymbol{u}_{C A d}=[10.05 .0], \varphi_{C d}=-0.5236[\mathrm{rad}]$ $(=-30[\mathrm{deg}])$ とした。計画された軌道は計算結果はFig. 6 に 示されている. ここで, $i_{1}=2, i_{2}=1, l_{R}=8.4699, l_{M}=$ 16.0212 である。 また, $\varphi_{C}$ の最終的な値は $\varphi_{C}=-0.5226$ と なり，目標値が正確に実現されていることが分かる.

次に, 計画された軌道を用いてシミュレーションを行った。シ ミュレーションではソフトウェアとして ADAMS (Mechanical Dynamic, Inc.) を用い, Fig. 7 に示すような関節構成の 2 自 由度マニピュレータのモデルを構成した， 6.2 節で提案した方法 で計算された軌道を, 式 $(9)$ により等価な関節軌道に変換し, マニピュレータの目標関節軌道とした。シミュレーション結果は Fig. 8 に示されている.ここで，(a) は全軌道を 36 秒でたどっ た場合であり，(b) は 360 秒でたどった場合である．本研究で は仮定 1 で準静的な運動を仮定し，また，マニピュレータを駆 動する場合も接触座標を直接フィードバックしていない.よっ て，マニピュレータを速く動かすと追従誤差が生じる可能性が ある. Fig. 8(a) では対象物が摇れたため, 途中の軌道が若干振

†証明は付録に示す。

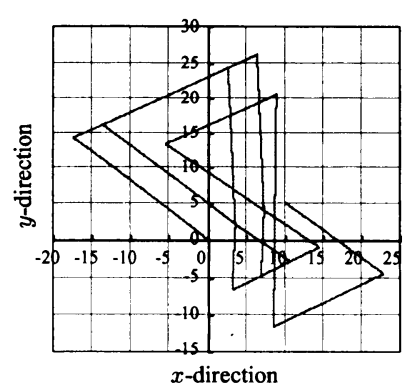

(a) Locus of contact point on the plane

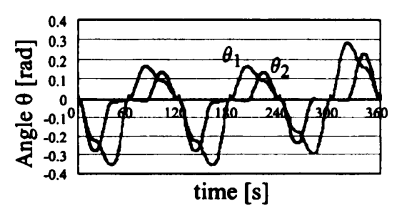

(b) Joint angle

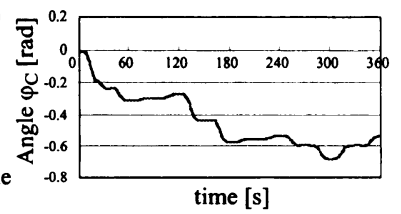

(c) Angle of object
Fig. 6 Result of trajectory planning

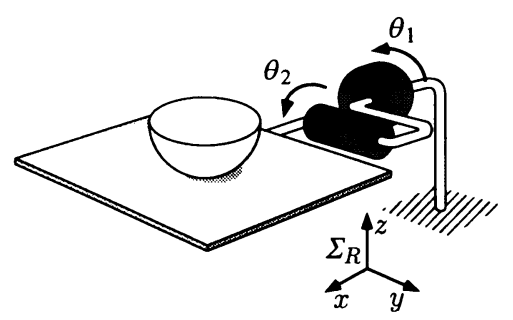

Fig. 7 Robot system used for simulation

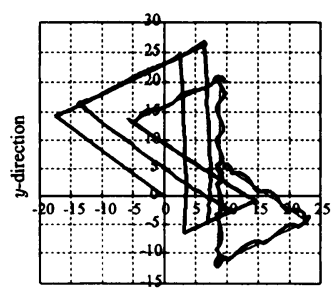

$x$-direction

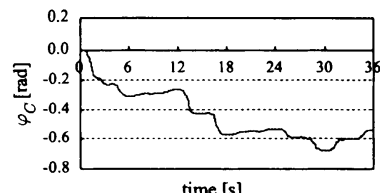

(a) Results of rapid motion

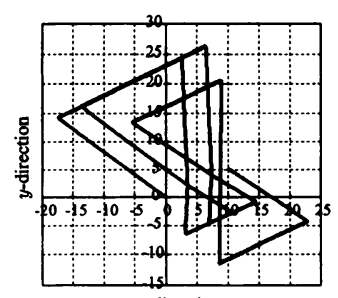

$x$-direction

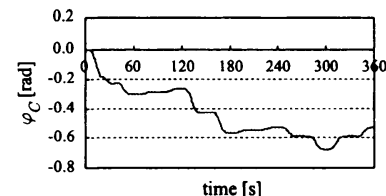

(b) Results of slow motion
Fig. 8 Simulation results

動的だが, 最終的にほほ目標值が実現されていることが分かる. 一方, Fig. 8(b) では対象物は正確に目標軌道を追従し, 最終的 に $\boldsymbol{u}_{C A}=[10.06025 .1181]^{T}, \varphi_{C}=-0.5303[\mathrm{rad}]$ となった。 また, Fig. 9 はシミュレーションを行っている際の ADAMS の グラフィック画面を示している.

\section{8. 実験}

次に，実機実験を行った。実験では Fig. 10 に示すような 2 自由度マニピュレータ（NEXUS AVS-III）を用いた。対象物 としては, 半径が 22.0 [mm] (対象物 A) と $23.5[\mathrm{~mm}]$ (対象物 B）の 2 種類の半球を用いた. 対象物と平板の間の摩擦を増加 させるために, 対象物としてはゴムの対象物を用い, 平板の上 に紙を貼った。

まず, 対象物上の接触点軌道として正三角形を一つ描く目標 


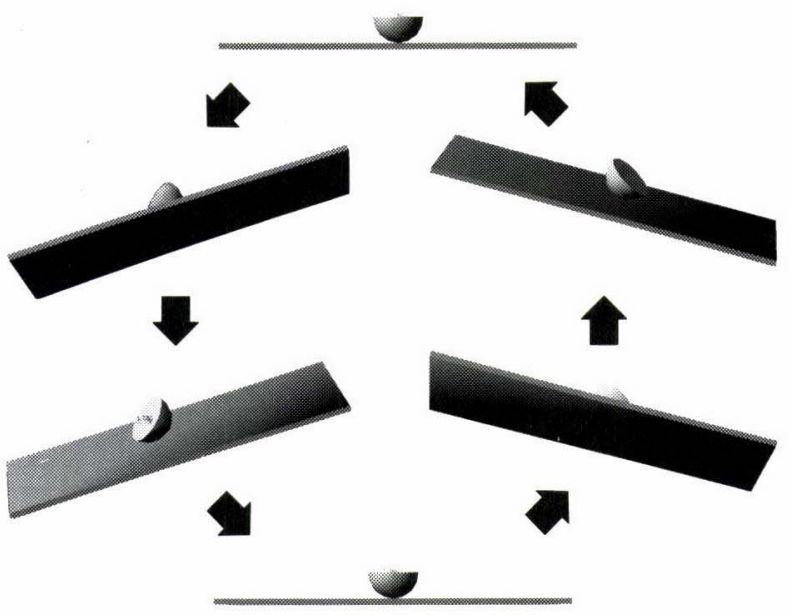

Fig. 9 Graphics of ADAMS during simulation

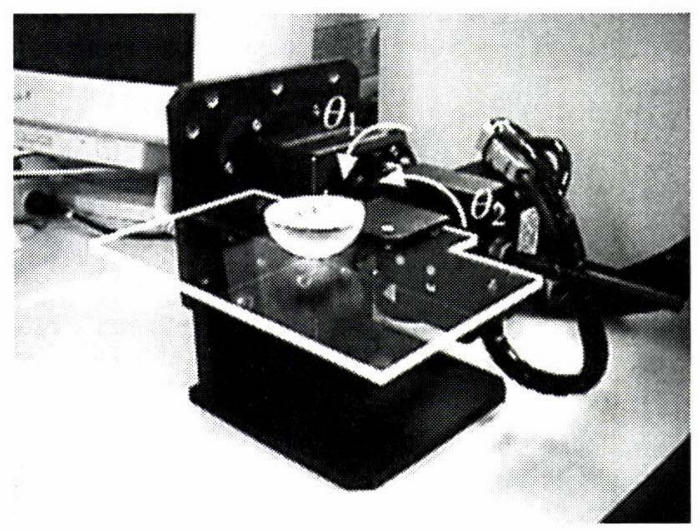

Fig. 10 Robot system used for experiment

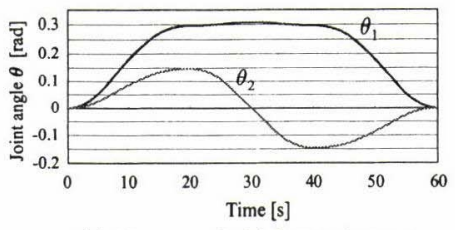

(a) Commanded joint trajectory

\begin{tabular}{cccc}
$\langle$ Object A $\rangle$ & $x$-direction $[\mathrm{mm}]$ & $y$-direction $[\mathrm{mm}]$ & $\varphi_{C}[\mathrm{rad}]$ \\
\hline Simulation result & 3.936 & -0.002 & -0.361 \\
\hline Experimental result & $3.754 \pm 0.043$ & $-0.172 \pm 0.047$ & $-0.346 \pm 0.003$ \\
\hline
\end{tabular}

(b) Result of object $\mathrm{A}$

\begin{tabular}{cccc}
$<$ Object B $>$ & $x$-direction $[\mathrm{mm}]$ & $y$-direction $[\mathrm{mm}]$ & $\varphi_{C}[\mathrm{rad}]$ \\
\hline Simulation result & 3.256 & -0.001 & -0.299 \\
\hline Experimental result & $3.308 \pm 0.120$ & $-0.022 \pm 0.015$ & $-0.300 \pm 0.006$ \\
\hline
\end{tabular}

(c) Result of object B

Fig. 11 Result of experiment drawing one triangle

軌道を与えて実験を行った。まず，式（9）により計算された関 節軌道を Fig. 11 (a) に示す。この関節軌道をマニピュレータに 追従させた結果を Fig. 11 (b)，（c）に示す。ここで，実験結果で は10 回試行した平均值と標準偏差が,シミュレーション結果と 比較して示されている。結果より分かるように, 実験結果とシ
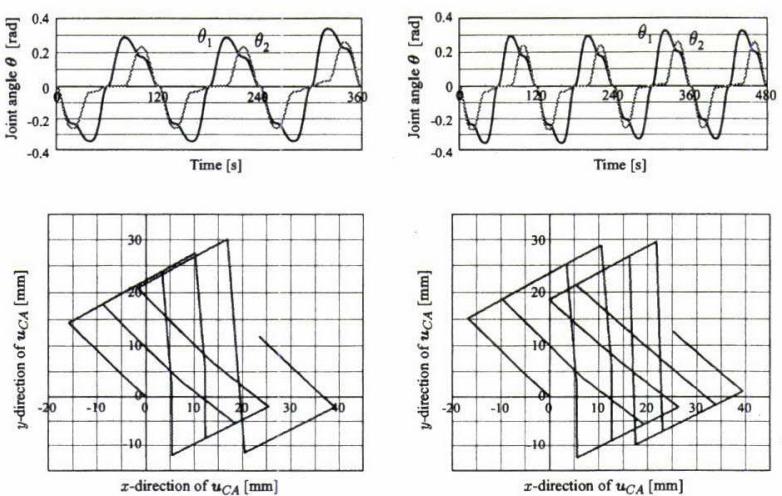

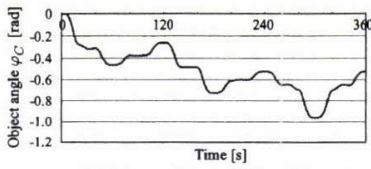

(a) Planned values for object $\mathrm{A}$

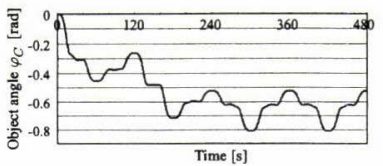

(b) Planned values for object B
Fig. 12 Planned trajectories for object A and B

Table 1 Experimental results

\begin{tabular}{cccc}
$\langle$ Object A $>$ & $x$-direction $[\mathrm{mm}]$ & $y$-direction $[\mathrm{mm}]$ & $\varphi_{C}[\mathrm{rad}]$ \\
\hline Desired values & 23.57 & 11.79 & -0.524 \\
\hline Experimental result & $20.68 \pm 0.41$ & $11.50 \pm 0.29$ & $-0.428 \pm 0.021$ \\
\hline
\end{tabular}

(a) Result of object A

\begin{tabular}{cccc}
$<$ Object B $>$ & $x$-direction $[\mathrm{mm}]$ & $y$-direction $[\mathrm{mm}]$ & $\varphi_{C}[\mathrm{rad}]$ \\
\hline Desired values & 25.18 & 12.59 & -0.524 \\
\hline Experimental result & $26.14 \pm 0.49$ & $13.90 \pm 0.25$ & $-0.328 \pm 0.022$
\end{tabular}

(b) Result of object B

ミュレーション結果はほとんど一致しており，実験結果が正確 であることが分かる。

次に，目標の接触座標を実現させる実験を行った，接触座標 の目標值は対象物 A, B に対してそれぞれ, $\boldsymbol{u}_{C A d}=[23.57$ $11.79][\mathrm{mm}] \varphi_{C d}=-0.524[\mathrm{rad}], \boldsymbol{u}_{C A d}=\left[\begin{array}{ll}25.18 & 12.59\end{array}\right][\mathrm{mm}]$ $\varphi_{C d}=-0.524[\mathrm{rad}]$ とした。 6.2 節の手法により計算され た目標軌道を Fig. 12 に示す。実験結果は Table 1 に示さ れている. 最終的に接触座標は対象物 $\mathrm{A}$ に対して $\boldsymbol{u}_{C A}=$ [20.68 11.50] [mm], $\varphi_{C}=-0.428[\mathrm{rad}]$, 対象物 B に対して $\boldsymbol{u}_{C A}=[26.1413 .90][\mathrm{mm}], \varphi_{C}=-0.328[\mathrm{rad}]$ となっている. 若干の誤差が生じているが，ほほ目標値が実現されている。

\section{9. 結訔}

本論文では, 重力平衡する対象物の操り問題について議論し た。対象物上に接触安定領域を定義し, その領域内で軌道計画 を行う手法を提案した。 また，接触座標の軌道が与えられたと きに対応するアームの関節軌道を導出する方法の提案を行った. また，提案する手法の有効性をシミュレーションや実験により 確認した。フィードバック制御器を構成することは今後の課題 である、最後に，本研究を進める上で有益な助言を頂いた広島 大学工学部助教授の辻敏夫先生に感謝いたします. 


\section{参考 文 献}

（1］原田，金子：“重力場における複数対象物の平衡把握とそのロバスト 性”, 日本ロボット学会誌, vol.17, no.1, pp.133-139, 1999.

[2] W.S. Howard and V. Kumar: "On the Stability of Grasped Objects," IEEE Trans. on Robotics and Automation, vol.12, no.6, pp.904-917, 1996.

[3] J. Kerr and B. Roth: "Analysis of Multifingered Hands," The Int. J. of Robotics Research, vol.4, no.4, pp.3-17, 1986.

[4] D.J. Montana: "The Kinematics of Contact and Grasp," The Int. J. of Robotics Research, vol.7, no.3, pp.17-32, 1988.

[5] Z. Li and J. Canny: "Motion of Two Rigid Bodies with Rolling Constraint," IEEE Trans. on Robotics and Automation, vol.6, no.1, pp.62-72, 1990.

[6] A.B.A. Cole, J.E. Hauser and S.S. Sastry: "Kinematics and Control of Multifingered Hands with Rolling Contacts," IEEE Trans. on Automatic Control, vol.34, no.4, pp.398-404, 1989.

[ 7 ] E. Paljug, X. Yun and V. Kumar: "Control of Rolling Contacts in Multi-Arm Manipulation," IEEE Trans. on Robotics and Automation, vol.10, no.4, pp.441-452, 1994.

[ 8 ] N. Sarkar, X. Yun and V.Kumar: "Dynamic Control of 3-D Rolling Contacts in Two-Arm Manipulation," IEEE Trans. on Robotics and Automation, vol.13, no.3, pp.364-376, 1997.

[9] A. Bicchi and R. Sorrentino: "Dextrous Manipulation Through Rolling," Proc. of 1995 IEEE Int. Conf. on Robotics and Automation, pp.452-457, 1995

[10] 三平, 水野, 石川, 古賀：“2 板間に挟まれて運動する剛球の位置制 御”, 日本ロボット学会誌, vol.14, no.8, pp.1237-1242, 1996.

[11] L. Han, Y.S. Guan, Z.X. Li, Q. Shi and J.C. Trinkle: "Dextrous Manipulation with Rolling Contacts," Proc. of 1997 IEEE Int. Conf. on Robotics and Automation, pp.992-997, 1997.

[12] R.M. Murray, Z. Li and S.S. Sastry: A Mathematical Introduction to Robotic Manipulation. CRC Press, 1994.

[13] J.C. Trinkle, A.O. Farahat and P.F. Stiller: "Second-Order Stability Cells of a Frictionless Rigid Body Grasped by Rigid Fingers," Proc. of 1994 IEEE Int. Conf. on Robotics and Automation, pp.2815-2821, 1994.

[14] M. Kaneko, M. Kessler, K. Harada and T. Tsuji: "Necessary and Sufficient Number of Fingers for Capturing Pyramidal-like Objects," Proc. of IEEE/RSJ Int. Conf. on Intelligent Robots and Systems (IROS98), pp.134-139, 1998.

[15] K.M. Lynch, N.Shiroma, H.Arai and K.Tanie: "The Roles of Shape and Motion in Dynamic Manipulation: The Butterfly Example," Proc. of 1998 IEEE Int. Conf. on Robotics and Automation, pp.1958-1963, 1998.

[16] 荒井, Khatib：“動的スキルによるマニピュレーションの基礎実験”, システム制御情報学会論文誌, vol.8, no.9, pp.506-508, 1995.

[17] R.M. Murray, Z.X. Li and S.S. Sastry: A Mathematical Introduction to Robotic Manipulation. CRC Press, 1994.

[18] K. Harada and M. Kankeo: "Enveloping Grasp for Multiple Objects," Proc. of 1998 IEEE Int. Conf. on Robotics and Automation, pp.2409-2415, 1998.

[19] D.J. Montana: "Contact Stability for Two-Fingered Grasps," IEEE Trans. on Robotics and Automation, vol.8, no.4, pp.421$430,1992$.

[20] 小林：曲線と曲面の微分幾何．裳華房，1977.

\section{付録 A. 接触状態の記述}

接触座標の幾何学的関係式を導出する. $\left[\begin{array}{lll}v_{x} & v_{y} & v_{z}\end{array}\right]^{T}$, $\left[\omega_{x} \omega_{y} \omega_{z}\right]^{T}$ をそれぞれ $\Sigma_{L O}$ からみた $\Sigma_{L A}$ に対する $\Sigma_{L O}$ の 並進, 回転速度とする. $\boldsymbol{u}_{C O} \in R^{2}, \boldsymbol{u}_{C A} \in R^{2}, \varphi_{C} \in R^{1}$ は 以下のように表される [4].

$$
\begin{aligned}
\dot{\boldsymbol{u}}_{C O} & =\mathcal{M}_{O}^{-1}\left(\boldsymbol{\mathcal { K }}_{O}+\tilde{\mathcal{K}}_{A}\right)^{-1}\left(\left[\begin{array}{c}
-\omega_{y} \\
\omega_{x}
\end{array}\right]-\tilde{\mathcal{K}}_{A}\left[\begin{array}{c}
v_{x} \\
v_{y}
\end{array}\right]\right) \\
\dot{\boldsymbol{u}}_{C A} & =\mathcal{M}_{A}^{-1} \boldsymbol{R}_{\varphi}\left(\mathcal{K}_{O}+\tilde{\mathcal{K}}_{A}\right)^{-1}\left(\left[\begin{array}{c}
-\omega_{y} \\
\omega_{x}
\end{array}\right]+\mathcal{K}_{O}\left[\begin{array}{c}
v_{x} \\
v_{y}
\end{array}\right]\right) \\
\dot{\varphi}_{C} & =\omega_{z}+\mathcal{T}_{O} \mathcal{M}_{O} \dot{\boldsymbol{u}}_{C O}+\mathcal{T}_{A} \mathcal{M}_{A} \dot{\boldsymbol{u}}_{C A} \\
v_{z} & =0
\end{aligned}
$$

ここで, Pure Rollingの条件として, $v_{x}=v_{y}=\omega_{z}=0$ を考 慮し,さらに

$$
\left[\begin{array}{lll}
\omega_{x} & \omega_{y} & \omega_{z}
\end{array}\right]^{T}=\boldsymbol{R}_{L O}^{T}\left(\boldsymbol{\omega}_{O}-\boldsymbol{\omega}_{A}\right)
$$

を代入することで, 式 (2) が得られる.また, 同様に式 $(3)$ も 得られる. 最後に, この接触座標のモデル化は $\partial \boldsymbol{f}_{O} / \partial \boldsymbol{u}_{C O}^{T}$ の 各列が直交することを仮定している．球体では直交関係が満足 されるが，楕円体などはこの直交関係が必ずしも満足されない. この場合, 適当な座標変換を行う必要がある.

\section{付録 B. 近 傍 平 衡 [1]}

平衡が崩れた場合でも，平板上を転がって他の平衡点に移動す る近傍平衡のメカニズムを定式化する. 式 (1) を $\dot{\boldsymbol{x}}_{O}$ について解 くことを考える. $\dot{\boldsymbol{x}}_{O}$ について解くため, 新たな変数 $\dot{\boldsymbol{\lambda}}=\boldsymbol{E}_{O} \dot{\boldsymbol{x}}_{O}$ を設ける.この変数 $\dot{\boldsymbol{\lambda}}$ は行列 $\operatorname{rank}\left[\left(\boldsymbol{D}_{O} \boldsymbol{T}_{O}\right)^{T} \boldsymbol{E}_{O}^{T}\right]^{T}=6$ と

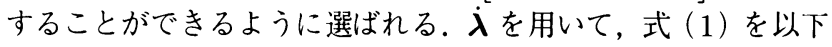
のとおりに $\dot{\boldsymbol{x}}_{O}$ について解くことができる.

$$
\begin{aligned}
\dot{\boldsymbol{x}}_{O} & =\left[\begin{array}{c}
\boldsymbol{D}_{O} \boldsymbol{T}_{O} \\
\boldsymbol{E}_{O}
\end{array}\right]^{+}\left[\begin{array}{c}
\boldsymbol{D}_{A} \boldsymbol{J} \dot{\boldsymbol{\theta}} \\
\dot{\boldsymbol{\lambda}}
\end{array}\right] \\
& \triangleq \boldsymbol{H}_{A} \dot{\boldsymbol{\theta}}+\boldsymbol{H}_{G} \dot{\boldsymbol{\lambda}}
\end{aligned}
$$

ここで, $\left[\left(\boldsymbol{D}_{O} \boldsymbol{T}_{O}\right)^{T} \boldsymbol{E}_{O}^{T}\right]^{T}$ は列フルランクであるため, 零空 間は存在しない.つまり, $\dot{\boldsymbol{\theta}}, \dot{\boldsymbol{\lambda}}$ が与えられた場合, 式 (B.2)に より $\dot{\boldsymbol{x}}_{O}$ を一意に求めることができる.ここで, Fig. 1 (a) に示 すような単一対象物の単一アームによる操りでは, アームの関 節を固定しても対象物は平板上を転がることが可能であり， が関節変数が決定された後に残る元長性を表している.

次に，仮に対象物が平衡状態にないとする。このとき，対象 物はポテンシャルエネルギが小さくなる方向に移動する．対象 物のポテンシャルエネルギは以下により与えられる.

$$
U=m \boldsymbol{g}^{T} \boldsymbol{x}_{O}
$$

式 (B.3) の微分に式 (B.2) を考慮すると, 次式が得られる.

$$
\dot{U}=m \boldsymbol{g}^{T}\left(\boldsymbol{H}_{A} \dot{\boldsymbol{\theta}}+\boldsymbol{H}_{G} \dot{\boldsymbol{\lambda}}\right)
$$

準静的な運動を仮定すると，アームが微小変位して瞬間的に平 衡が崩れると, 対象物は位置エネルギーが最も減少する方向に 移動して再び平衡が保たれると考えられる，つまり，入の変化 量は最急降下法により次式で与えられる。

$$
\dot{\boldsymbol{\lambda}}^{T}=-\epsilon \boldsymbol{g}^{T} \boldsymbol{H}_{G}
$$



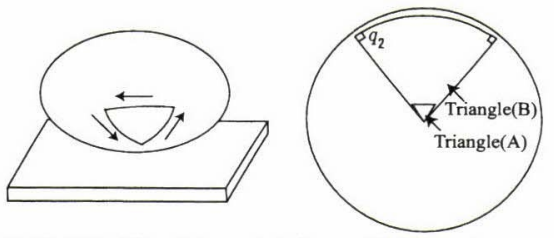

(a) Overview of triangle by geodesic line

(b) Bottom view
Fig. 13 Triangle by geodesic line

€は微小量である。対象物が式（1）に示される拘束の下で式 (B.5)により示さ机る方向に移動し, 最終的に $\dot{U}=0$ となる点 に到達すると，対象物は再び平衡すると考えられる，次に，平衡 状態にあるとき成立する関係式を導く。準静的な運動では，各 瞬間においてアームを静止させると, その状態で平衡が成立す る. 式（B.5）を式（B.4）に代入し, さらに $\dot{\boldsymbol{\theta}}=0, \dot{U}=0$ を 考慮する。つまり，各瞬間で次式が成立する.

$$
\Theta\left(\boldsymbol{x}_{O}, \boldsymbol{\theta}, \boldsymbol{u}\right)=\boldsymbol{H}_{G}^{T} \boldsymbol{g}=0
$$

なお，平衡状態では対象物重心が接触点の真上にある性質を利 用すると, 式 (B.6) の代わりに, 次の式を仮定することもで きる。

$$
\Theta\left(\boldsymbol{x}_{O}, \boldsymbol{\theta}, \boldsymbol{u}\right)=\left[\begin{array}{ll}
\boldsymbol{I}_{2} & \mathbf{0}
\end{array}\right] \boldsymbol{R}_{O}{ }^{O} \boldsymbol{p}_{C O}=0
$$

式（B.6）はその偏導関数を導出するときに, 数值微分を行わな ければならないのに対して, 式 (B.7) では解析的に導関数が導 出できるところに特徴がある.

\section{付録 C．測地線による正三角形に関する補足}

本章では，測地線による正三角形について，いくつかの補足 事項を示す. $\boldsymbol{u}_{C O}=\left[\begin{array}{ll}u^{1} & u^{2}\end{array}\right]^{T}$ とおく.このとき, 測地線は次 の微分方程式で表される $[20]$.

$$
\frac{d^{2} u^{i}}{d s^{2}}+\sum_{j, k}^{1,2} \Gamma_{j k}^{i} \frac{d u^{j}}{d s} \frac{d u^{k}}{d s}=0 \quad(i=1,2)
$$

ここで, $s$ は曲線上の距離を表すパラメータであり, $\Gamma_{j k}^{i}$ は Christoffel の記号である.この測地線を回転楕円体上に描く. また，測地線を用いた四形として正三角形を描く（Fig. 13）。測 地線を接平面に射影すると直線となる性質を利用し, 次のよう な手順で正三角形を描くことができる.

[A1] 回転楕円体の極から長さが $l$ の 2 本の経線を描く.

[A2] 2 本の経線の端点を結ぶ測地線を描く. 端点を結ぶ測地線 が 2 本以上ある場合は，距離が最も短いものを選択する。

[A3] 2 本の経線の間の角度を変更しながら [A1], [A2] を繰り 返し，端点を結ぶ測地線のうち長さが $l$ のものを見つける.

このアルゴリズムを用いることにより，正三角形を一意に求 めることができる。三角形は最大でも Fig. 13 (b) に示す三角形 (B)とする.このとき, 内角に関して次のことがいえる.

[定理 2]：内角の単調性

三角形の辺の長さに対して, 内角の大きさは単調に変化する.

[証明]：Fig. 13 (b) に示すように，辺の長さが最小の三角形 $(\mathrm{A})$ から三角形 $(\mathrm{B})$ まで, 序々に辺の長さを増やす。内角 $q_{2}$ に着 目する. 三角形 $(\mathrm{B})$ では $q_{2}=\pi / 2$ である. $q_{2}$ が単調増加しな いとすると，違う辺長に対して内角が同じ三角形が存在するこ とになる。三角形 $(\mathrm{B})$ より小さい三角形で $q_{2}=\pi / 2$ の三角形 が存在する場合を考える。測地線は接触点で平面に射影すると 直線であることを考慮し, 三角形 $(\mathrm{B})$ より小さい三角形を描く ために経線から $q_{2}=\pi / 2$ の角度で測地線を描き始めると, 赤 道を跨いでしまい正三角形は描けないことが分かる。また, 三 角形 $(\mathrm{B})$ より小さい三角形の場合，それより小さな三角形で同 じ内角を有するものがないことも，測地線は接触点で平面に射 影すると直線であることより分かる。つまり, 内角は辺長に対 して単調に変化する.

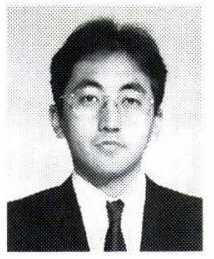

原田研介 (Kensuke Harada)

1968 年 9 月 28 日生. 1997 年 3 月京都大学大学 院工学研究科機械工学専攻博士後期課程修了. 博士 (工学)。同年 4 月広島大学助手，現在に至る。ロ ボットハンド，ロボットマニピュレータの力学と制 御に関する研究に興味を持つ. IEEE，計測自動制 御学会, 日本機械学会などの会員.

(日本ロボット学会正会員)

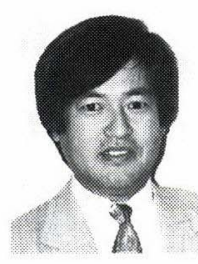

金子 真 (Makoto Kaneko)

1954 年 1 月 18 日生. 1976 年 3 月九州工業大学機 械工学科卒業. 1981 年 3 月東京大学工学系研究科 博士課程修了. 工学博士. 同年 4 月通産省工業技術 院機械技術研究所入所. 1990 年 4 月, 九州工業大学 情報工学部助教授. 1993 年 10 月広島大学教授, 現 在に至る。ロボットハンド，力覚センサ，触覚ベー ストアクティブセンシングなどの研究に興味を持つ. IEEE, 計測自 動制御学会, 日本機械学会などの会員。(日本ロボット学会正会員)

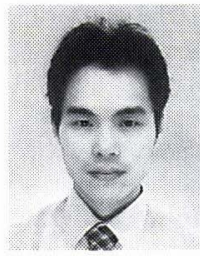

川嶋大雅 ( Taiga Kawashima)

1976 年 9 月 27 日生. 2000 年広島大学大学院工学 研究科情報工学専攻博士前期課程修了. 現在京七ラ (株) 勤務. 在学中ロボットハンドの力学と操りに 関する研究に興味を持つ。 